\title{
Therapeutic trial in experimental tegumentary leishmaniasis caused by Leishmania (Leishmania) amazonensis. A comparative study between mefloquine and aminosidine
}

\author{
Ensaio terapêutico na leishmaniose tegumentar experimental causada por \\ Leishmania (Leishmania) amazonensis. Um estudo comparativo \\ entre mefloquina e aminosidine
}

\author{
Letícia Oba Galvão, Sebastião Moreira Júnior, Pedro Medeiros Júnior, Gleiser José Piantino \\ Lemos, Nara Fabiana Cunha, Rosa Maria Parreiras Antonino, Bráulio Silva \\ Santos Filho and Albino Verçosa Magalhães
}

\begin{abstract}
One hundred and eighty-two male inbred C57/BL/6 mice were infected with $3 \times 10^{6}$ Leishmania (Leishmania) amazonensis promastigotes of the MHOM/BR/PH8 strain by means of a subcutaneous injection in the right ear. The animals were separated in three groups: 1) oral mefloquine hydrochloride treatment (16mg/kg/day/10 days), 2) intramuscular aminosidine (Paromomycin $\Theta)$ treatment (20mg/kg/20 days) and 3) control. Twenty six mice of each treated group were sacrificed, one at the end of treatment (nine weeks after inoculation), and one six weeks later (fifteen weeks after inoculation). Control Group animals were sacrificed at weeks six, nine and fifteen after inoculation. There was no significant difference between Group 1 (mefloquine) and Group 3 (control) subjects. Group 2 animals (aminosidine) presented the smallest differences of all, both at the end of the treatment and six weeks later. The histopato-logical parameters have shown the following findings: a) there was no significant difference between the mefloquine treated group and the control group; the group treated with aminosidine showed fewer of vacuolated macrophages than the control group, at week 9 (end of treatment). b) both at the end of treatment and six weeks later, evaluation of tissue necrosis and tissue fibrosis revealed no differences between the treated groups. It was found that six weeks after the end of treatment, mice in the control group presented significantly more severe degrees of fibrosis than mice in the other groups. It can be concluded that mefloquine showed limited therapeutic effect in this experimental model, whereas aminosidine had a significant effect. Nevertheless, neither of them resulted in cure of the lesions.
\end{abstract}

Key-words: Leishmania (Leishmania) amazonensis. Inbred C57/BL/6 mice. Mefloquine. Aminosidine.

Resumo Foram utilizados 182 camundongos machos, isogênicos, da linhagem C57BL/6 inoculados na orelha direita com 3,0 × $10^{6}$ formas promastigotas da cepa MHOM/BR/PH8 de Leishmania (Leishmania) amazonensis. Os animais foram separados em três grupos: 1) 52 animais tratados com mefloquina (16mg/ $\mathrm{kg} / \mathrm{dia} / 10 \mathrm{dias})$, 2) 52 animais tratados com aminosidina [Paramomicina (B] (20mg/kg/dia/20 dias), 3) 78 animais controles, não manipulados. Vinte e seis animais de cada grupo tratado foram sacrificados nove $e$ quinze semanas após a inoculação. Animais do grupo controle foram sacrificados na sexta, nona e décima quinta semanas após a inoculação. Ao final do tratamento, em relação à curva de peso da orelhas, somente nos animais tratados com aminosidina, houve nítida redução do peso em comparação com grupo controle. $\mathrm{Na}$ histopatologia verificou-se: a) não houve diferença entre o grupo tratado com mefloquina e o grupo controle; o grupo tratado com aminosidina, ao final do tratamento, teve menor infiltração por macrófagos vacuolizados; b) as avaliações da extensão das áreas de necrose e do nível da fibrose tecidual não mostraram diferenças entre os grupos tratados. Os animais do grupo controle apresentaram fibrose mais acentuada, seis semanas após o fim do tratamento. Pode-se concluir que ocorreu efeito terapêutico reduzido com a mefloquina e houve significativa melhora com a aminosidina. Entretanto, em todos os grupos as lesões não chegaram a curar.

Palavras-chaves: Leishmania (Leishmania) amazonensis. Camundongos isogênicos C57/BL/6. Mefloquina. Aminosidine.

Pathology Department of Medicine School of the University of Brasília, Brasília, DF.

Supported by FAPDF, CNPq and UnB.

Address to: Dr. Albino Verçosa Magalhães. Pathology Department/UnB, 70910-900 Brasília, DF, Brazil.

Fax: 5561 273-0105.

e-mail: albino@unb.br.

Recebido para publicação em 20/4/99 
American cutaneous leishmaniasis (ACL) is a disease caused by a flagellated protozoan that is an intracellular parasite of macrophages. In Brazil, the main species are: Leishmania (Viannia) braziliensis, L. (Viannia) guyanensis, L. (Viannia) lainsoni and L. (Leishmania) amazonensis ${ }^{1}$. In Latin America, 39 million people are at risk of contracting the disease, and about 59,000 new cases are reported each year. In 1995, the incidence was of 22.81 cases per 100,000 inhabitants (total 35,664 cases), $115 \%$ higher than in $1985^{4}$.

The drugs recommended as first choice by the Ministry of Health here in Brazil are the pentavalent antimonials: meglumine antimoniate (Glucantime ${ }^{\circledR}$ ) and sodium stibogluconate (Pentostam ${ }^{\circledR}$ ). However, these drugs require parenteral administration under medical supervision, usually for long periods of time, and have many side effects ${ }^{3456789101220}$, which are a frequent reasons for interrupting or suspending therapy. In view of the considerable difficulties encountered when establishing prophylactic programs, and of the adverse effects of pentavalent antimonials, the search for new drugs to control this disease is called for.

Landires et al ${ }^{14}$ reported a successful clinical trial with mefloquine hydrochloride by oral administration in 17 patients with cutaneous leishmaniasis in Ecuador. That study offered a promising approach for the treatment of leishmaniasis and was the chief motivation for the present experiment, designed to compare the therapeutic efficacy of mefloquine with that of aminosidine, a well-known leishmanicide ${ }^{16}$. Mefloquine ${ }^{11} 1518$ is a quinolone derivate which has been used traditionally for the treatment of malaria by oral administration, which constitutes the great advantage in its possible use for the treatment of cutaneous leishmaniasis. Aminosidine is an aminoglycoside antibiotic that has been used for the treatment of $A C L$ with a high rate of disease resolution and with few side effects ${ }^{1217}$.

\section{MATERIAL AND METHODS}

Animals. One hundred and eighty-two male inbred $\mathrm{C} 57 / \mathrm{BL} / 6$ mice were infected with $0,05 \mathrm{ml}$ each of a suspension containing $3 \times 10^{6}$ Leishmania (Leishmania) amazonensis [L.(L)a] promastigotes of the MHOM/BR/PH8 strain by means of a subcutaneous injection in the right ear. The animals were divided into three groups, so that 52 mice were treated with mefloquine and 52 with aminosidine, and 78 were used as controls.

Therapeutic outlines. At the end of the $6^{\text {th }}$ week of infection, the following therapeutic plan was initiated - Group 1: mefloquine $16 \mathrm{mg} / \mathrm{kg} / \mathrm{day}$, for 10 days, by enteric administration; Group 2: aminosidine [Paromomycin] 20mg/kg/day, for 20 days, intramuscularly; and Group 3 animals (controls) received no drug.

Evaluation of the lesions. Twenty six mice of each treated group were killed, at the end of treatment (nine weeks after inoculation) and six weeks later (fifteen weeks after inoculation). Group 3 animals were killed at week six, nine and fifteen after inoculation. Once each animal was killed, both of its ears were cut off at their bases, and then uniformly sized using a bidimensional millimeter ruler, and weighed so as to determine the exact difference in weight between the right and left ears. The infected right ears were fixed in $10 \%$ formaldehyde and processed by the usual methods of histotechnology.
Weight difference between ears. The intensity of the inflammatory process in the right, infected ears was assessed by comparing their weights to those of the uninfected left ears. Increase in weight in the infected ear was considered to reflect the extent of inflammatory phenomena such as vascular reaction, edema and cellular exudation.

Histopathologic evaluation of the lesions. Histologic features were evaluated using a graduation scale, as described by Magalhães et $\mathrm{a}^{15}$. Three events were analyzed: vacuolated macrophages, cellular necrosis (acute and subacute necrosis), and connective tissue reaction (fibrosis). Since semiquantitative values with an asymmetric distribution were obtained, the geometric average of each parameter was used when comparing treatments.

Vacuolated macrophages. These occurred consistently in the cellular response to infection by Leishmania (Leishmania) amazonensis during the study, indicating an immune tolerance reaction caused by the intense parasitic activity within the lesions. They were assessed semiquantitatively, i.e. in comparison to non-vacuolated macrophages.

Cellular necrosis (acute and subacute necrosis). This was a very frequent alteration that occurred in two subtypes representing different stages of the same kind of tissue change. In the acute necrosis there was disintegration of vacuolated macrophages and parasites, coupled 
with variable exudation of normal and disintegrated neutrophils. In subacute necrosis, varying degrees of fibrin filament deposition (fibrinoid necrosis) took the place of the neutrophils, which were not to be found. The two types could be assessed by the extension and frequency of the areas of necrosis that were observed.

Conjunctive tissue reaction (fibrosis). This event was consistent with the natural resolution of an inflammatory process. In the animal models, it resulted from the resolution of successive episodes of necrosis, and was measured by the appropriate parameters for this type of alteration. Fibrosis (scarring) portrays a healing answer of the host to the necrosis that follows parasitic aggression.

Statistical analysis. In comparing the weight of ears between groups, the $t$ test for independent observations was adopted, and outlier values were excluded. All parameters of the animals excluded from the test were also excluded from analysis. Histopathologic findings were analyzed using the Mann-Whitney test.

\section{RESULTS}

Weight difference between ears. There was no significant difference between Group 1 (mefloquine) and Group 3 (control) animals. Group 2 animals (aminosidine) presented the smallest differences of all, both at the end of the treatment and six weeks later, but there was a significant statistical difference $(p<0,05)$ after the end of the treatment (Figure 1).

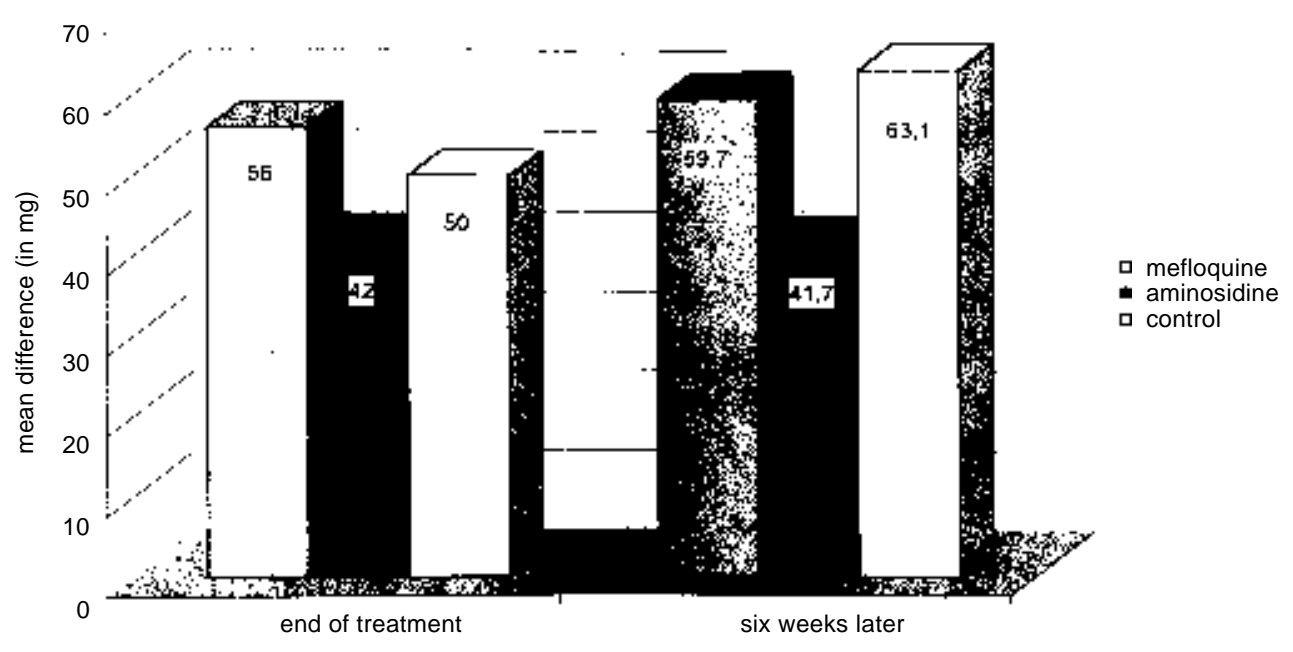

Figure 1 - Average difference in weight between right and left ears.

Histopatologic evaluation of the lesions. The following results were observed:

Vacuolated macrophages. There was no significant difference between the mefloquine treated group and the control group. The group treated with aminosidine showed fewer of these cells than the control group, at week 9 (end of treatment) $(p<0,05)$. Specimens obtained from animals sacrificed at week 15 (six weeks after treatment) revealed no significant statistical difference in any comparison between groups $(p>0,05)$ (Figure 2).
Necrosis. In the evaluation of cellular necrosis it was verified that there were no significant statistical differences between groups, wether at the end of the treatment or six weeks later. The following statistical values were obtained: $p=0.14$ for the comparison between aminosidine and mefloquine, $p=0.08$ for the comparison between aminosidine and controls and $p=0.37$ for the comparison between mefloquine and controls (Figure 3).

Fibrosis. At the end of treatment (week 9), there were no significant statistical differences 


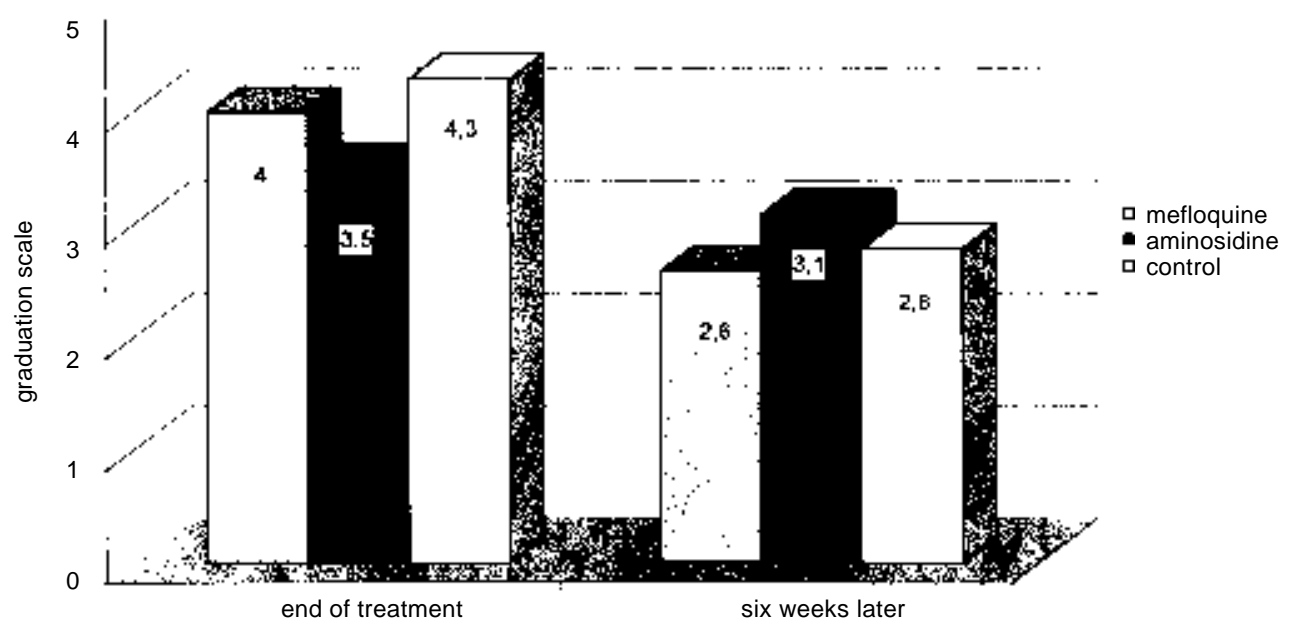

Figure 2 - Grade of vacuolated macrophages in treated and control groups.

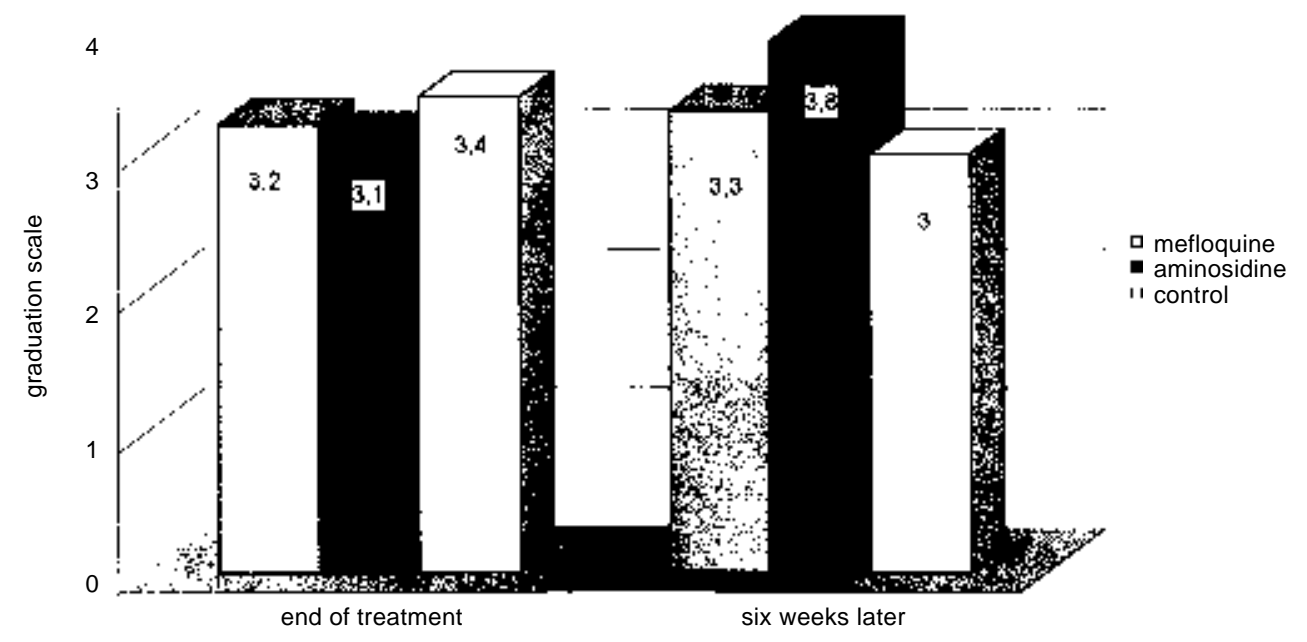

Figure 3 - Tissue necrosis in treated and control groups.

between groups as far as tissue fibrosis is concerned. However, six weeks after the end of treatment (week 15), animals in the control group presented a significantly more severe degree of fibrosis $(p<0,05)$ than animals in the other two groups (Figure 4). 


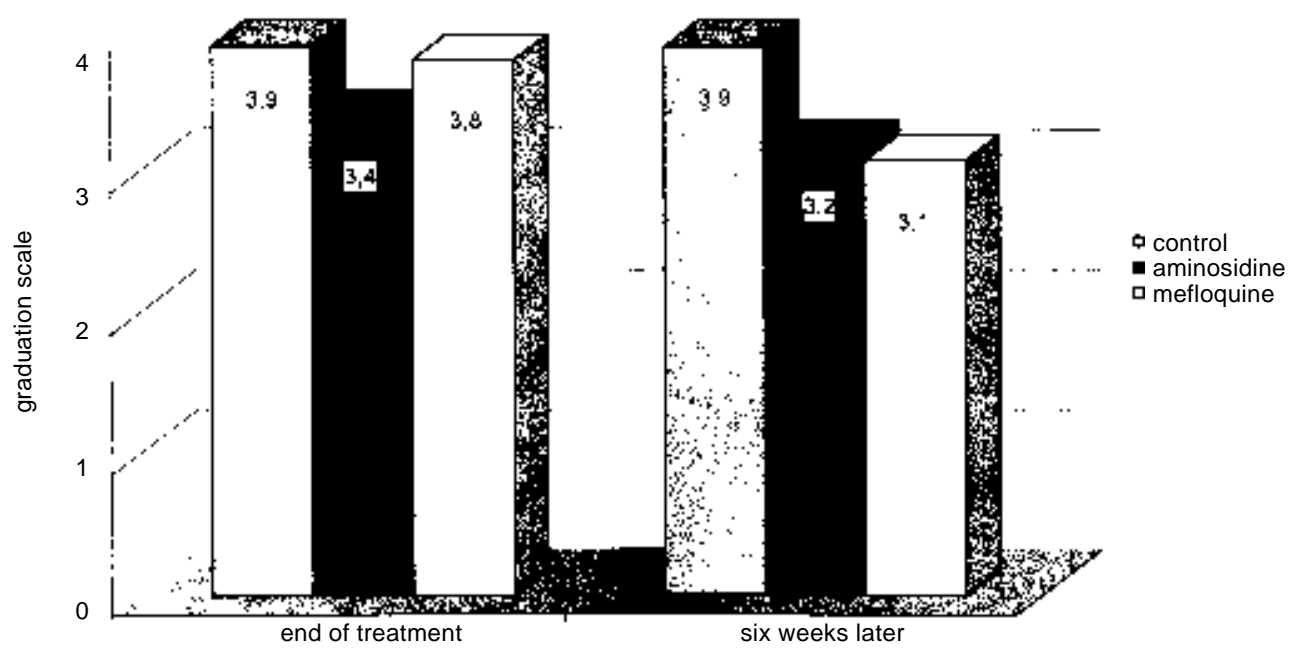

Figure 4 - Conjunctive reaction (fibrosis) in treated and control groups.

\section{DISCUSSION}

The work of Landires et $\mathrm{al}^{14}$, demonstrating the successful use of mefloquine in the treatment of human cases of ACL, served as motivation for the present experimental therapeutic trial aiming to assess the beneficial effects of mefloquine in ACL. Mefloquine has proven to be an easily administered drug that has few side effects ${ }^{11} 131518192122$, and could therefore provide an easier, widespread form of treatment for this disease, particularly in rural areas.

The results obtained in this study show that the mice treated with aminosidine displayed an appreciable reduction in the weight of their ears compared to the control group. The same was not true for the group treated with mefloquine, whose ponderal difference remained close to the levels observed in the control group, even six weeks after treatment: this reflects an inefficacy of the drug as regards this parameter.

Evaluating the participation of the vacuolated macrophages, it was verified that there was a significant reduction in their numbers only in the group of animals treated with aminosidine. This observation indicates that aminosidine had an important effect in the reduction of tissue parasitism. In the group of animals treated with mefloquine, however, the same did not occur: data obtained six weeks after treatment were slightly different from the control group, but there was no significant statistical difference.

Both at the end of treatment and six weeks later, evaluation of tissue necrosis and tissue fibrosis revealed no differences between the treated groups. It was found that six weeks after the end of treatment, mice in the control group presented significantly more severe degrees of fibrosis than mice in the other groups.

It can be concluded that mefloquine showed limited therapeutic effect in this experimental model, whereas aminosidine had a significant effect. Nevertheless, neither of them resulted in cure of the lesions. It is possible that the discrepancy between our results and the ones reported by Landires et al could be due to difference in parasite species involved in the two studies: in the study carried out in Ecuador, the species used was Leishmania (Viannia) panamensis, whereas the species used in our study was Leishmania (Leishmania) amazonensis, which displays a different kind of antigenic and biological behavior.

\section{REFERENCES}

1. Antezana G, Zeballos R, Mendoza C, Lyevre $P$ Valda L, Cardenas F, Noriega I, Ugarte H, Dedet P. Electrocardiographic alterations during treatment of mucocutaneous leishmaniasis with antimoniate and allopurinol. Transactions of the Royal Society of Tropical Medicine and Hygiene 86:31-33, 1992. 
2. Berman JD. Chemotherapy for Leishmaniasis: biochemical mechanisms, clinical efficacy, and future strategies. Reviews of Infectious Diseases 10:560-586, 1988.

3. Bryceson ADM, Scott JAG, Davidson RN, Moody $A H$, Grant HR, Felmingham D, Scott GMS, Oliaro P. Aminosidine (paromomycin) in the treatment of leishmaniasis imported into the United Kingdom. Transactions of the Royal Society of Tropical Medicine and Hygiene 82:617-619, 1992.

4. Castro C, Sampaio N, Marsden PD. Severe arthralgia, not related to doses, associated with pentavalent antimonial therapy for mucosal leishmaniasis. Transactions of the Royal Society of Tropical Medicine and Hygiene 84:362, 1990.

5. Cook CG. Leishmaniasis: recent developments in chemotherapy. Journal of Antimicrobial Chemotherapy 31:327-330, 1993.

6. Fundação Nacional de Saúde. Guia de Controle da Leishmaniose Tegumentar Americana. Ministério da Saúde, 3ª edição, Brasília, 1994.

7. Gasser RA, Magill AJ, Oster CN, Franke ED, Grögl M, Berman JD. Pancreatitis induced by pentavalent antimonial agents during treatment of leishmaniasis. Clinical and Infectious Diseases, 18:83-90, 1994.

8. Gilman AG, Goodman LS, Gilman A. As bases farmacológicas da terapêutica. $8^{a}$ edição, Rio de Janeiro, Guanabara-Koogan, 1991.

9. Grogl M, Thomason TN, Frande ED. Drug resistance in leishmaniasis: its implication in systemic chemotherapy of cutaneous and mucocutaneous disease. American Journal of Tropical Medicine and Hygiene 47:117-126, 1992.

10. Hennequin C, Bourée P, Bazin N, Bisaro F, Feline A. Severe psychiatric side effects observed during prophylaxis and treatment with Mefloquine. Archives of Internal Medicine 154:2360-2362, 1994.

11. Hepburn NC. Thrombocytopenia complicating sodium stibogluconate therapy for cutaneous leishmaniasis. Transactions of the Royal Society of Tropical Medicine and Hygiene 87:691, 1993.

12. Hunter JAA, Hepburn NC, Tidman MJ. Aminosidine (paromomycin) versus sodium stibogluconate for the treatment of American cutaneous leishmaniasis. Transactions of the Royal Society of Tropical Medicine and Hygiene 88:700-703, 1994.

13. Karbwang J, Na Bangchang K, Thanavibul A, Back DJ, Bunnag D, Harinasuta T. Pharmacokinetics of mefloquine alone or in combination with artesunate. Bulletin of the World Health Organization 72:83-87, 1994.

14. Landires EAG, Andrial M, Hosakawa A, Nonaka S, Hashigushi Y. Oral treatment of New World cutaneous leishmaniasis with mefloquine and artesunate in Ecuador: The preliminary clinical trial. Japanese Journal of Tropical Medicine and Hygiene 23:151-157, 1995.

15. Magalhães AV, Moraes MA, Raick AN, Llanos-Cuentas A, Costa JM, Cuba CC, Marsden PD. Histopatologia da Leishmaniose Tegumentar por Leishmania braziliensis braziliensis. 1. Padrões histopatológicos e estudo evolutivo das lesões. Revista do Instituto de Medicina Tropical de São Paulo 28:253-262, 1986.

16. Neves DP. Parasitologia Humana. $8^{a}$ edição, Atheneu, São Paulo, 1991.

17. Olliaro P, Soto J, Grogl M, Berman J. Limited efficacy of injectable Aminosidine as the single-agent therapy for Colombian cutaneous leishmaniasis. Transactions of the Royal Society of Tropical Medicine and Hygiene 88:695698, 1994.

18. Schlagenhauf $P$, Steffen R. Stand-by treatment of malaria in travelers: the review. Journal of Tropical Medicine and Hygiene 95:151-160, 1994.

19. Sowunmi A, Salako LA, Oduola AMJ, Walker O, Akindele JA, Ogundahunsi OAT. Neuropsychiatric side effects of Mefloquine in Africans. Transactions of the Royal Society of Tropical Medicine and Hygiene 87:462463, 1993.

20. Speich R, Haller A. Central anticholinergic syndrome with the antimalarial drug Mefloquine. New England Journal of Medicine 331:57-58, 1994.

21. Well JL, Kerr L, Stuerchler D. Mefloquine prophylaxis: in the overview of spontaneous reports of several psychiatric reactions and convulsions. Journal of Tropical Medicine and Hygiene 95:167-179, 1992.

22. White NJ. Mefloquine. British Medical Journal 308:286287, 1994. 